\title{
Torcetrapib impairs endothelial function in hypertension
}

\author{
Branko Simic $^{1 \dagger}$, Matthias Hermann ${ }^{1,2 \dagger}$, Sidney G. Shaw ${ }^{3}$, Laurent Bigler ${ }^{4}$, Urs Stalder ${ }^{4}$, \\ Carola Dörries ${ }^{1}$, Christian Besler ${ }^{1}$, Thomas F. Lüscher ${ }^{1,2}$, and Frank Ruschitzka ${ }^{1,2 *}$
}

${ }^{1}$ Department of Cardiovascular Research, Institute of Physiology, University of Zurich, Zurich, Switzerland; ${ }^{2}$ Department of Cardiology, Cardiovascular Center, University Hospital Zurich, CH-8091 Zurich, Switzerland; ${ }^{3}$ Department of Clinical Research, Medical Faculty of the University of Bern, Bern, Switzerland; and ${ }^{4}$ Department of Organic Chemistry, University of Zurich, Zurich, Switzerland

Received 14 April 2011; revised 27 July 2011; accepted 15 August 2011; online publish-ahead-of-print 14 September 2011

This paper was guest edited by Prof. Dr Thomas Münzel, Johannes Gutenberg Universität, Mainz, Germany See page 1548 for the editorial comment on this article (doi:10.1093/eurheartj/ehr408)

Aims A marked increase in HDL notwithstanding, the cholesterol ester transfer protein (CETP) inhibitor torcetrapib was associated with an increase in all-cause mortality in the ILLUMINATE trial. As underlying mechanisms remain elusive, the present study was designed to delineate potential off-target effects of torcetrapib.

Methods and results Spontaneously hypertensive rats (SHRs) and Wistar-Kyoto (WKY) rats were treated with torcetrapib $(100 \mathrm{mg} / \mathrm{kg} /$ day; SHR-T and WKY-T) or placebo (SHR-P and WKY-P) for 3 weeks. Blood pressure transiently increased during the first 3 days of torcetrapib administration in SHRs and returned to baseline thereafter despite continued drug administration. Acetylcholine-induced endothelium-dependent relaxations of aortic rings were markedly impaired, and endothelial nitric oxide synthase (eNOS) mRNA and protein were down-regulated after 3 weeks of torcetrapib treatment in SHR $(P<0.0001,<0.01$, and $<0.05$, resp. vs. SHR-P). Torcetrapib reduced NO release in cultured aortic endothelial cells $(P<0.01$ vs. vehicle-treated cells) and increased generation of reactive oxygen species in aortas of SHR-T $(P<0.05$, vs. SHR-P). Vascular reactivity to endothelin-1 (ET-1) and aortic ET-1 tissue content were increased in SHR-T $\left(P<0.05\right.$ vs. SHR-P). Importantly, the ET-1 receptor $A / B\left(E T_{A / B}\right)$ antagonist bosentan normalized endothelial function in SHR-T $(P<0.05)$.

Conclusion Torcetrapib induces a sustained impairment of endothelial function, decreases eNOS mRNA, protein as well as NO release, stimulates vascular ROS and ET production, an effect that is prevented by chronic $\mathrm{ET}_{\mathrm{A} / \mathrm{B}}$-receptor blockade. These unexpected off-target effects of torcetrapib need to be ruled out in the clinical development of novel CETP inhibitors, particularly before a large patient population at increased cardiovascular risk is exposed to these compounds.

Keywords

HDL • CETP inhibition • Endothelin • Endothelial dysfunction • Nitric oxide

\section{Introduction}

The plasma levels of high-density lipoprotein $(\mathrm{HDL})$ cholesterol are inversely related to cardiovascular risk. ${ }^{1-3}$ Currently available HDL-raising therapies are associated with undesirable side effects, limited efficacy, or have not yet been shown to improve morbidity and mortality on top of statins in clinical outcome trials. ${ }^{4-6} \mathrm{~A}$ novel pharmacological target for raising circulating HDL-C levels is the cholesterol ester transfer protein (CETP), an enzyme involved in the physiological process of reverse cholesterol transport in humans, by which excess cholesterol is removed from peripheral tissues, and then returned to the liver for secretion into the bile. Conceptually, inhibition of CETP thus provides an attractive therapeutic target. ${ }^{7}$ Indeed, three pharmacological small-molecule inhibitors of CETP, i.e. dalcetrapib (JTT-705; Roche), anacetrapib (Merck), and torcetrapib (Pfizer), have been developed. The molecules effectively raise HDL-C by $60-100 \%$ in humans either when used as a monotherapy or in combination with statins.

\footnotetext{
${ }^{\dagger}$ B.S. and M.H. contributed equally to this work.

*Corresponding author. Tel: +41 4425539 57, Fax: +41 25587 01, Email: frank.ruschitzka@usz.ch

Published on behalf of the European Society of Cardiology. All rights reserved. C The Author 2011. For permissions please email: journals.permissions@oup.com
} 
Surprisingly and in spite of a marked increase in HDL-C and a reduction in LDL-C levels, an unexpected increase in all-cause mortality, including cardiovascular and non-cardiovascular events, was observed in patients treated with torcetrapib in the Investigation of Lipid Level Management to Understand Its Impact in Atherosclerotic Events (ILLUMINATE) study. ${ }^{8}$ Furthermore, three large imaging trials using coronary intravascular ultrasound and carotid intima-media thickness demonstrated a lack of efficacy of torcetrapib on coronary atheroma burden or carotid intima-media thickness, respectively, again in spite a marked increase in HDL levels. ${ }^{9-11}$ The molecular mechanisms for this excess in cardiovascular morbidity and mortality and lack of anti-atherosclerotic efficacy remain still elusive.

It is of note that the use of torcetrapib was associated with an increase in blood pressure (BP) in ILLUMINATE as well as in clinical trials of the early development phase. ${ }^{9-13}$ As the potent CETP inhibitors dalcetrapib and anacetrapib are devoid of such pressor effects, ${ }^{14-17}$ the BP elevation associated with torcetrapib may represent an off-target effect specific for this molecule. Importantly, in the ILLUMINATE study, a moderate decrease in potassium and slight increase in sodium and bicarbonate was observed in the torcetrapib group, suggesting a potential mineralocorticoid effect of torcetrapib. $^{8}$

Thus, the aim of the present study was to delineate underlying potential off-target effect(s) of torcetrapib in experimental hypertension. As endothelial function may be an obvious target of the compound, we investigated specifically, whether and to what degree torcetrapib impacts on this well-established surrogate for cardiovascular risk.

\section{Methods}

\section{Animals}

Male spontaneously hypertensive rats (SHRs) and Wistar-Kyoto (WKY) rats, 16-20 weeks old, mean weight $320 \mathrm{~g}$, were purchased from Charles River Laboratories (Research Models and Services, Germany $\mathrm{GmbH}$ ). Animals were fed a normal chow diet and had ad libitum access to food and water, maintained at $24^{\circ} \mathrm{C}$ under a $12 \mathrm{~h}$ light/dark cycle. Torcetrapib (CP-529414 Spray-dried dispersion, LOT ID FP-04-069, kindly provided by Pfizer Inc., Groton, CT, USA) or placebo was given as a suspension in $0.5 \%$ methyl cellulose in a final concentration $100 \mathrm{mg} / \mathrm{kg} /$ day p.o. (oral gavage), for a total duration of 3 weeks. Dosage of torcetrapib was adjusted for body weight and calculated on a daily basis. In addition, animals were co-treated with the endothelin (ET)-receptor antagonist bosentan $100 \mathrm{mg} / \mathrm{kg} /$ day (Actelion Pharmaceuticals Ltd, Switzerland) together with torcetrapib. Systolic BP and heart rate were measured by tail-cuff method (model LE 5002, Storage Pressure Meter, Letica, Spain) after intensive training of the animals.

Study design and experimental protocols fully complied with the guidelines for research animal use by the American Heart Association and were approved by the institutional animal care committee (Licence Nr. 17/2008, Kommission für Tierversuche des Kantons Zürich, Switzerland).

\section{Tissue harvesting and organ chamber experiments}

At the end of the 21-day treatment, animals were first anaesthetized using pentobarbital $(50 \mathrm{mg} / \mathrm{kg}$ i.p.) and sacrificed by blood exsanguinations. Blood was drawn into Li-Heparin-coated vacutainers (Vacutainer ${ }^{\circledR}$ Heparin Tubes, Additive Lithium Heparin (68 USP), $\mathrm{BD})$ and plasma was isolated. Aorta was removed and placed in cold $\left(4^{\circ} \mathrm{C}\right)$ modified Krebs-Ringer bicarbonate solution.

The aorta was cleaned from connective tissue and cut into rings of $3 \mathrm{~mm}$ length. The remaining aortic tissue was snap frozen in liquid nitrogen for further analysis. Aortic rings were placed in an organ bath for isometric tension recording as described elsewhere. ${ }^{18}$ Shortly after $60 \mathrm{~min}$ of an equilibration, the rings were progressively stretched to their optimal passive tension $(3 \mathrm{~g})$. Rings were preconstricted with norepinephrine (NE, $\sim 70 \%$ of $100 \mathrm{mM} \mathrm{KCl}$ ) and relaxations to acetylcholine ( $\mathrm{ACh}, 10^{-10}$ to $10^{-5} \mathrm{M}$ ) or sodium nitroprusside (SNP, $10^{-10}$ to $10^{-5} \mathrm{M}$ ) were obtained. In additional experiments, vasoconstriction to ET-1 $\left(10^{-10}\right.$ to $\left.10^{-1} \mathrm{M}\right)$ and concentration-response curves to $\operatorname{NE}\left(10^{-10}\right.$ to $\left.10^{-5} \mathrm{M}\right)$ were obtained. In addition, vascular reactivity to ET-1 was performed in the presence of selective ET-1 receptor $A\left(E T_{A}\right)$ and $E T-1$ receptor $\mathrm{B}\left(\mathrm{ET}_{\mathrm{B}}\right)$ antagonists, $\mathrm{BQ}-123$ and $\mathrm{BQ}-788\left(10^{-6} \mathrm{M}\right)$, respectively, preincubating the rings with the antagonists for $30 \mathrm{~min}$ before ET-1 was added.

All organ chamber experiments were performed in the presence of indomethacin $\left(10^{-5} \mathrm{M}\right)$, a non-selective inhibitor of cyclooxygenase-1 and -2 (COX-1 and COX-2, respectively). Chemicals used in the organ bath were obtained from Sigma Aldrich (Buchs, Switzerland) apart from ET-1 and big ET-1, which were purchased from Bachem (Bubendorf, Switzerland). After experiments, vessel rings were blotted dry and weighted.

\section{RNA and Western blot}

RNA was extracted from frozen aortic tissue pulverized on a stainless steel mortar by hammering. Purification of total RNA was performed as described in RNeasy ${ }^{\circledR}$ Mini Handbook (Qiagen AG, Hombrechtikon, Switzerland). The primers and probe used for RT-PCR analysis were: rat endothelial nitric oxide synthase (eNOS), forward primer: 5'-CTA CCG GGA CGA GGT ACT GG-3', backward primer: 5'-GGA AAA GGC GGT GAG GAC TT-3' (Microsynth Balgach, Switzerland), probe: 5'-CGC CCA GCA GCG TGG AGT GTT T-3', 5'-End Fam, 3'-TAMRA Probe, (Applied Biosystems Rotkreuz, Switzerland), human vascular cell adhesion molecule 1 (VCAM-1): forward: 5'-GTC TCC AAT CTG AGC AGC AA-3',backward: 5'-TGG GAA AAA CAG AAA AGA GGT G- 3', human inter-cellular adhesion molecule 1 (ICAM-1): forward: 5'-AGG GTA AGG TTC TTG CCC AC-3', backward: 5'-TGA TGG GCA GTC AAC AGC TA-3', human L28: forward: 5'-GCA ATT CCT TCC GCT ACA AC-3', backward: 5'-TGT TCT TGC GGA TCA TGT GT-3', rat VCAM-1: forward: 5'-GCG AAG GAA ACT GGA GAA GAC A- 3', backward: 5'-ACA CAT TAG GGA CCG TGC AGT T- 3', rat ICAM-1: forward: 5'-TTT CGA TCT TCC GAC TAG GG-3', backward: 5'-AGC TTC AGA GGC AGG AAA CA-3', rat iNOS: forward: 5'-CAG ATC CCG AAA CGC TAC AC-3', backward: 5'-TGC GGC TGG ACT TCT CAC T-3', rat GAPDH: forward: 5'-TGC CAA GTA TGA TGA CAT CAA GAA G- 3', backward: 5'-AGC CCA GGA TGC CCT TTA GT-3'(Microsynth AG, Balgach, Switzerland).

Pulverized aortic tissue for Western blot analysis was further homogenized in the ice-cold lysis buffer $[150 \mathrm{mM} \mathrm{NaCl}, 50 \mathrm{mM}$ Tris, $\mathrm{pH}$ 7.4, 1\% NP-40, $1 \mathrm{mM}$ EDTA, 1 Protease Inhibitor Cocktail Tablet (Roche complete EDTA-free, Roche, Switzerland), phosphatase inhibitor cocktail 1 and 2 (Sigma Aldrich, Buchs, Switzerland)]. Protein extract concentration was measured by the Bradford method ${ }^{19}$ and $50 \mu \mathrm{g}$ of protein extract was loaded on a $10 \%$ polyacrylamide-SDS gel for electrophoresis, as described previously. ${ }^{20}$ Endothelial NO 
synthase was detected using eNOS antibody (eNOS, SantaCruz, 1:200; $2^{\circ}$ :antirabbit-POD, 1:2500, GE Healthcare, UK), and for a normalization $\beta$-actin antibody was used ( $\beta$-actin, Sigma, 1:20 000; $2^{\circ}$ :antimousePOD, 1:20 000, GE Healthcare, UK). Blot visualization was performed by ImageReader Fuji Film LAS-300 (FujiFilm Corporation, Tokyo, Japan). Quantification of the band intensities was performed using AIDA Image Analyzer software (Raytest Schweiz AG, Wetzikon, Switzerland). For expression analysis of the adhesion molecules following antibodies were used: human VCAM-1: anti hVCAM-1, BBA19, R\&D Systems ( $\left.{ }^{\circ} \mathrm{Ab}-1: 1000 ; 2^{\circ} \mathrm{Ab}-1: 2500\right)$, human ICAM-1: anti- CD54 (ICAM-1), 07-5403, Invitrogen ( $\left.1^{\circ} \mathrm{Ab}-1: 1000 ; 2^{\circ} \mathrm{Ab}-1: 5000\right)$, rat VCAM-1: VCAM-1 (C-19), sc-1504, Santa Cruz Biotechnology, Inc. (1 $\left.{ }^{\circ} \mathrm{Ab}-1: 500 ; 2^{\circ} \mathrm{Ab}-1: 5000\right)$, rat ICAM-1: ICAM-1 (M-19), sc-1511, Santa Cruz Biotechnology, Inc. (1 $\left.{ }^{\circ} \mathrm{Ab}-1: 500 ; 2^{\circ} \mathrm{Ab}-1: 5000\right)$, rat iNOS: NOS2 (H-174), sc-8310, Santa Cruz Biotechnology, Inc. ( $1^{\circ} \mathrm{Ab}-1: 500$; 2Ab-1:5000), GAPDH: anti-GAPDH, MAB374, Millipore (1 $\left.{ }^{\circ} \mathrm{Ab}-1: 10000 ; 2^{\circ} \mathrm{Ab}-1: 20000\right)$.

\section{Endothelin-1 determination}

Tissue ET-1 level was determined as described previously. ${ }^{21}$ Briefly, tissue was hydrolyzed in $0.1 \mathrm{M}$ acetic acid at $80^{\circ} \mathrm{C}$, and then thoroughly homogenized using a polytron homogenizer. After centrifugation, extraction was performed using a standard peptide extraction procedure, by adsorption on prewashed Sep-Pak Vac C18 (500 mg) cartridges (Millipore). The ET-1 level was determined using radioimmunoassay and the recording was done using a $\gamma$ counter and the radioimmunoassay data processed using machine software (Canberra Packard).

\section{Immunohistochemistry}

Prior to histological analysis, samples were embedded in Tissue-Tek ${ }^{\circledR}$ O.C.T. ${ }^{\text {TM }}$ compound (Sakura Finetek Europe, Zoeterwoude, the Netherlands), frozen on dry ice and stored at $-80^{\circ} \mathrm{C}$. Cryosections of rat aortas $(7 \mu \mathrm{m})$ were fixed with freshly prepared $4 \%$ paraformaldehyde on SuperFrost ${ }^{\circledR}$ (SuperFrost, Braunschweig, Germany) slides. Endogenous peroxidase activity was blocked by dipping the slides for 5 min in a $3 \% \mathrm{H}_{2} \mathrm{O}_{2}$-methanol solution. Slides were further incubated in a humid chamber at $4{ }^{\circ} \mathrm{C}$ overnight with or without first antibody against rat $\mathrm{ET}_{\mathrm{A}}$ and $\mathrm{ET}_{\mathrm{B}}$ receptors (1:10 dilution; Alomone Labs Ltd, Jerusalem, Israel). After washing in phosphate-buffered saline, affinitypurified biotin-conjugated goat anti-rabbit antibody (Dako, Glostrup, Denmark) was applied for $60 \mathrm{~min}$ at room temperature in a humid chamber. Slides were then exposed to avidin-biotin-horseradish peroxidase complex prepared from the reagents supplied by Dako (Glostrup, Denmark, Cat. no. KO355) during 45 min. Bound peroxidase was detected after $3 \mathrm{~min}$ incubation at room temperature with 3,3'-diaminobenzidine substrate (Sigma, St Louis, MO, USA). Sections were finally counterstained briefly with haematoxylin (Merck, Darmstatt) and mounted in Aquatex (Merck).

Intensity was scored by an independent observer in at least three different samples and unaware of the groups and treatments. In order to evaluate the integrity of the endothelium and vascular smooth muscle layers, some samples were stained with von Willebrand factor (Dako) and smooth muscle actin (Dako). To evaluate possible background reactions, procedures were also performed in sections incubated with the provided control peptide antigen (Alomone Labs Ltd.) in excess.

\section{Plasma electrolytes and lipids}

Plasma electrolytes $\left(\mathrm{Na}^{+}, \mathrm{K}^{+}\right.$, and $\mathrm{Cl}^{-}$) and plasma lipids (HDL-C, LDL-C, and total cholesterol) were determined using standard enzymatic method on an automated analyser (Hitachi 912, Roche Diagnostics AG system, Rotkreuz, Switzerland).

\section{Plasma aldosterone, renin, and angiotensin II levels}

Plasma aldosterone, renin, and angiotensin levels were determined using commercially available ELISA kits (aldosterone: Alpha Diagnostic International, San Antonio, TX, USA; renin and angiotensin II: Cusabio Biotech Co., Ltd, Newark, DE, USA).

\section{Cell culture}

Human aortic endothelial cells (HAECs) were obtained from Clonetics ${ }^{\circledR}$. In 60-mm culture dishes, HAECs were grown in endothelial basal medium $\left(\right.$ Clonetics $\left.^{\circledR}\right)$, in a humidified atmosphere $\left(37^{\circ} \mathrm{C}, 95 \%\right.$ air $15 \% \mathrm{CO}_{2}$ ). Media was supplemented with $10 \%$ Foetal calf serum and EGM ${ }^{\mathrm{TM}}$-2 SingleQuots ${ }^{\circledR}$ (Cat. no. CC-4176, Clonetics ${ }^{\circledR}$ ). After confluence, cells were rendered quiescent by incubation in medium with $0.5 \%$ serum for $24 \mathrm{~h}$ and then stimulated with vehicle methanol and torcetrapib pure drug (CP-529414, Lot ID 052301-001-21, Pfizer Inc.) for additional $24 \mathrm{~h}$. At $24 \mathrm{~h}$ time point, $1000 \mu \mathrm{L}$ media were removed from each dish for the cell viability assay using Cytotoxicity Detection Kit (LDH, Cat. no. 11644793 001, Roche). Cells were lysed in ice cold lysis buffer as described above. Lysates were frozen at $-80^{\circ} \mathrm{C}$ until Western blot analysis.

\section{Measurement of endothelial cell nitric oxide production by electron spin resonance spectroscopy}

The effects of torcetrapib $\left(1000 \mathrm{nM} ; 24 \mathrm{~h}\right.$ at $\left.37^{\circ} \mathrm{C}\right)$ on endothelial NO production (HAECs; passage number 4-6; Clonetics ${ }^{\circledR}$ ) was examined by electron spin resonance (ESR) spectroscopy using the spin-probe colloid $\mathrm{Fe}(\mathrm{DETC})_{2}$ (Noxygen, Elzach, Germany), as described previously. ${ }^{22}$ In brief, ESR spectra of samples frozen in liquid nitrogen were recorded on a Bruker e-scan spectrometer (Bruker BioSpin, Billerica, MA, USA) with the following instrumental settings: centre field (B0) $3455 \mathrm{G}$, sweep width $80 \mathrm{G}$, microwave power $39.72 \mathrm{db}$, amplitude modulation $10.34 \mathrm{G}$, sweep time $10.49 \mathrm{~s}$, and number of scans 10. The intensity values for $\mathrm{NO}$ were normalized to the amount of protein within each sample, as detected by the Bio-Rad Protein assay (Reinach, Switzerland).

\section{Measurement of superoxide production in rat aorta by electron spin resonance spectroscopy}

Superoxide production was determined in rat descending aorta sections by ESR spectroscopy using the spin probe 1-hydroxy-3-methoxycarbonyl-2,2,5,5-tetramethyl-1-pyrrolidine and an e-scan ESR spectrometer (Bruker BioSpin). Time-dependent formation of superoxide was analysed using the following instrumental settings: centre field $1.99 \mathrm{~g}$, microwave power $20 \mathrm{~mW}$, modulation amplitude $2 \mathrm{G}$, sweep time $60 \mathrm{~s}$, field sweep $60 \mathrm{G}$. The intensity of ESR spectra was quantified after calibration of ESR signals with the free radical 3-carboxy-2,2,5,5-tetramethyl-1-pyrrolidinyloxy. The intensity values were divided by the dry weight of aorta sections.

\section{Calculations and statistical analysis}

Data are presented as mean \pm SEM. Contraction or relaxation (as per cent pre-contraction in rings pre-contracted to $70-80 \%$ of contraction induced by potassium chloride, $100 \mathrm{mM}$ ), negative logarithm of the concentration causing half-maximal relaxation or contraction $\left(\mathrm{EC}_{50}\right.$ 
value), and area under the curve were determined for each individual dose-response curve by non-linear regression analysis using GraphPad Prism 5.0 software for Windows (GraphPad Software, San Diego, CA, USA, www.graphpad.com). For comparing two groups, an unpaired Student's $t$-test was applied and, for multiple comparisons, the one-way ANOVA was used, followed by unpaired $t$-test for two-group-comparisons, when the ANOVA was significant. All statistical tests used were two sided. A value of $P<0.05$ was considered significant.

\section{Results}

\section{Animal characteristics and general data Systolic blood pressure}

Body weight and systolic BP were monitored throughout the entire duration of the study (Table 1). Systolic BP was elevated for 3 days after the start of torcetrapib administration in SHRs $(P<0.05)$, but not in WKY rats. However, BP returned to baseline after the third day and remained at initial levels despite continuous drug administration (Figure 1A). No change in BP was observed in WKY rats (Figure 1B).

\section{Torcetrapib plasma levels}

Plasma levels of torcetrapib were determined by UPLC-ESI-MS. The values averaged 0.648 and $0.820 \mu \mathrm{g} / \mathrm{mL}$, respectively, in SHR-T and WKY-T (Table 2).

\section{Plasma electrolytes and lipids}

Plasma levels of $\mathrm{K}^{+}$and $\mathrm{Cl}^{-}$were comparable for all groups. There was a tendency for lower $\mathrm{Na}^{+}$levels in SHR-T $(P=0.059$ vs.
SHR-P). No difference was detectable in WKY rats (Table 2). Plasma lipid levels remained unchanged (Table 2).

\section{Activity of the endothelial L-arigine/nitric oxide pathway}

Expression of endothelial nitric oxide synthase, VCAM-1, and ICAM-1 in cultured human aortic endothelial cells

Torcetrapib pure drug was used in cultured HAECs to investigate changes in $\mathrm{NO}$ bioavailability in vitro. The cell viability assay showed no torcetrapib-induced cellular toxicity $(10-3000 \mathrm{nM}$, Figure $2 \mathrm{~A})$. A marked down-regulation of total eNOS protein in HAECs treated with torcetrapib was observed $(-27.16,-35.35$, -37.09 , and $-37.74 \%$, for $100,500,1000$, and 3000 nM torcetrapib, respectively; $P<0.05$, for all torcetrapib concentrations vs. vehicle-treated cells) (Figure 2B). Both VCAM-1 and ICAM-1 were not differentially regulated in HAECs treated with torcetrapib vs. vehicle-treated HAECs, both at RNA and protein level (see Supplementary material online, Figure S6).

\section{Nitric oxide release in cultured human aortic endothelial cells}

In HAECs treated with torcetrapib, a marked reduction in NO release was observed as assessed by ESR spectroscopy $(-27.06 \%, P<0.01$ vs. vehicle-treated cells) (Figure $2 C$ ).

\section{Aortic expression of endothelial nitric oxide synthase,} inducible nitric oxide synthase, VCAM-1, and ICAM-1

Torcetrapib decreased eNOS mRNA and eNOS protein expression in the aortas of SHR as assessed by quantitative real-time PCR and Western blot analysis $(-43.91, P=0.008 ;-45.74, P=0.049$, vs. SHR-P, resp.) (Figure $3 A$ and $B)$. No difference in eNOS

Table I The main parameters analysed in torcetrapib-treated spontaneously hypertensive rats (SHR-T), placebo spontaneously hypertensive rats (SHR-P), torcetrapib-treated Wistar-Kyoto rats (WKY-T), and placebo Wistar-Kyoto rats (WKY-P)

\begin{tabular}{|c|c|c|c|c|}
\hline Parameter & SHR-T & SHR-P & WKY-T & WKY-P \\
\hline $\begin{array}{l}\text { Systolic blood pressure } \\
\quad(\mathrm{mmH}) \text {-area under the curve }\end{array}$ & $194.3 \pm 0.601^{*}, n=21$ & $190.5 \pm 0.292, n=19$ & $122.3 \pm 0.192, n=17$ & $121.4 \pm 0.161, n=13$ \\
\hline \multicolumn{5}{|l|}{ Body weight (g) } \\
\hline Day 1 & $308.3 \pm 6.039$ & $313.9 \pm 9.867$ & $294.3 \pm 5.420$ & $307.8 \pm 4.871$ \\
\hline Day 21 & $330.6 \pm 8.017$ & $345.8 \pm 10.860$ & $331.3 \pm 12.350$ & $361.0 \pm 7.703$ \\
\hline \multicolumn{5}{|l|}{ Acetylcholine } \\
\hline Area under the curve & $191.9 \pm 7.844^{\dagger}, n=11$ & $241.6 \pm 5.560, n=11$ & $234.6 \pm 9.371, n=4$ & $244.1 \pm 7.317, n=4$ \\
\hline $\mathrm{EC}_{50}(\mathrm{M}),-\log$ & $7.736 \pm 0.062^{\ddagger}, n=12$ & $7.989 \pm 0.056, n=11$ & $7.669 \pm 0.061, n=4$ & $7.743 \pm 0.050, n=4$ \\
\hline Maximum (\%) & $73.48 \pm 1.347^{\S}$ & $83.34 \pm 0.949$ & $88.37 \pm 1.018$ & $88.37 \pm 1.111$ \\
\hline \multicolumn{5}{|l|}{ Endothelin-1 } \\
\hline Area under the curve & $128.8 \pm 11.390^{\circ}, n=12$ & $96.84 \pm 8.332, n=10$ & $106.6 \pm 6.300, n=6$ & $97.17 \pm 3.289, n=4$ \\
\hline $\mathrm{EC}_{50}(\mathrm{M}),-\log$ & $7.998 \pm 0.044, n=9$ & $7.965 \pm 0.062, n=7$ & $7.890 \pm 0.058, n=6$ & $7.765 \pm 0.043, n=4$ \\
\hline
\end{tabular}

$* P<0.05$ SHR-T vs. SHR-P;

${ }^{\dagger} P<0.0001$ SHR-T vs. SHR-P.

${ }^{\ddagger} P<0.01$ SHR-T vs. SHR-P;

$\S p<0.0001$ SHR-T vs. SHR-P;

$\bullet p<0.05$ SHR-T vs. SHR-P. 


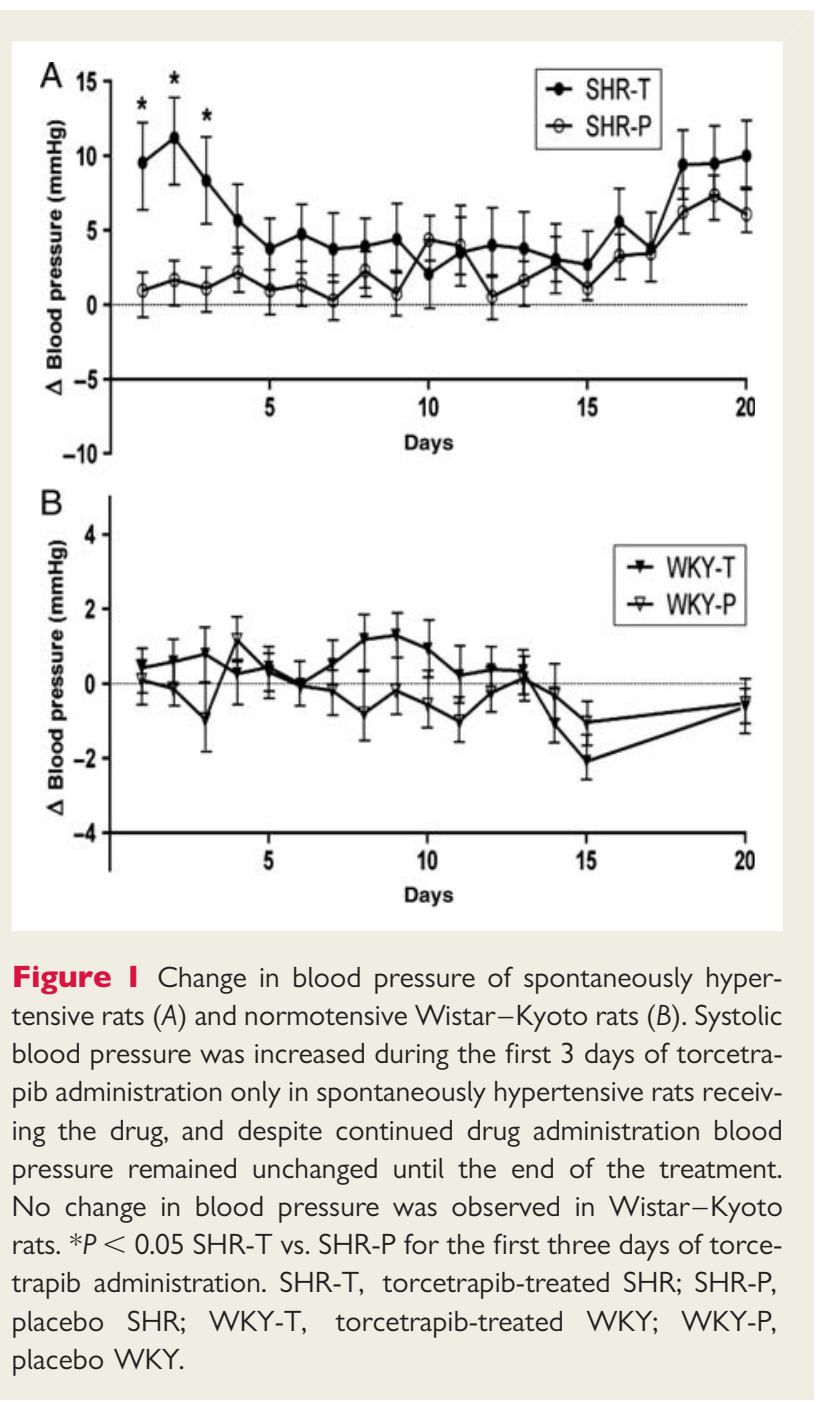

gene expression was found in torcetrapib-treated WKY rats $(P=0.5206$ vs. placebo-treated WKY rats) (Figure 3C). Both VCAM-1 and ICAM-1 were not differentially expressed in aortas of SHR-T and SHR-P, both at RNA and protein level (see Supplementary material online, Figure S7). Furthermore, iNOS expression was not changed in torcetrapib-treated SHR vs. placebotreated SHR (see Supplementary material online, Figure S8).

\section{Endothelium-dependent and endothelium-independent relaxation}

Torcetrapib induced impairment of endothelium-dependent relaxation to $\mathrm{ACh}$ in isolated aortic rings from SHR-T pre-contracted with NE $\left(P<0.0002\right.$ for $10^{-9} \mathrm{M} \mathrm{ACh}$, and $P<0.0001$ for $10^{-8}$, $10^{-7}, 10^{-6}$, and $10^{-5} \mathrm{M}$ ACh vs. SHR-P, Figure 4). Dose-response curves were used to determine $\mathrm{EC}_{50}$ value $(-\log [\mathrm{M}])$ between torcetrapib- and placebo-treated SHRs which were 7.736 and 7.989, for SHR-T and SHR-P, respectively $(P=0.0069)$. The area under the curve (AUC) was reduced in SHR-T $(-20.57 \%$, $P<0.0001$ vs. SHR-P, Table 1) as well as the maximal response $(-11.83 \%, P<0.0001$ vs. SHR-P). No difference in ACh-induced endothelium-dependent relaxation was observed between the rings isolated from torcetrapib-treated and placebo-treated WKY rats, respectively (Figure 4).

Endothelium-independent vasorelaxation to SNP $\left(10^{-10}\right.$ $\left.10^{-5} \mathrm{M}\right)$ did not reveal any difference between SHR-T and SHR-P (data not shown).

\section{Generation of reactive oxygen species}

To investigate the effects of tocretrapib on oxidative stress in vivo, the generation of reactive oxygen species (ROS) was measured in aortas of torcetrapib-treated (SHR-T) and placebo SHR (SHR-P) using ESR spectroscopy. The aortas of SHR treated with torcetrapib showed an increase in ROS production as assessed by ESR spectroscopy ( $+83.5 \%, P<0.05$ vs. SHR-P) (Figure 5).

Table 2 The main parameters analysed in torcetrapib-treated spontaneously hypertensive rats (SHR-T), placebo spontaneously hypertensive rats (SHR-P), torcetrapib-treated Wistar-Kyoto rats (WKY-T), and placebo Wistar-Kyoto rats (WKY-P). ( $n=5-12)$

\begin{tabular}{|c|c|c|c|c|}
\hline Parameter & SHR-T & SHR-P & WKY-T & WKY-P \\
\hline \multicolumn{5}{|l|}{ Plasma electrolytes, mM } \\
\hline $\mathrm{K}^{+}$ & $6.933 \pm 0.367$ & $6.764 \pm 0.314$ & $8.240 \pm 0.512$ & $7.880 \pm 0.397$ \\
\hline $\mathrm{Cl}^{-}$ & $88.91 \pm 1.436$ & $91.00 \pm 1.267$ & $90.40 \pm 0.748$ & $91.20 \pm 0.533$ \\
\hline $\mathrm{Na}^{+}$ & $144.2 \pm 0.964$ & $147.0 \pm 1.000$ & $142.0 \pm 0.633$ & $143.2 \pm 1.340$ \\
\hline \multicolumn{5}{|l|}{ Plasma lipids, mM } \\
\hline LDL-C & $0.2091 \pm 0.013$ & $0.2300 \pm 0.017$ & $0.2300 \pm 0.015$ & $0.2610 \pm 0.017$ \\
\hline HDL-C & $1.704 \pm 0.072$ & $1.810 \pm 0.072$ & $2.080 \pm 0.148$ & $2.126 \pm 0.078$ \\
\hline Total Cholesterol & $2.347 \pm 0.079$ & $2.565 \pm 0.081$ & $2.532 \pm 0.202$ & $2.736 \pm 0.125$ \\
\hline Renin, $\mathrm{mU} / \mathrm{mL}$ & $997.3 \pm 291.800$ & $653.3 \pm 149.200$ & n.d. & n.d. \\
\hline Torcetrapib, $\mu g / m L$ & $0.648 \pm 0.549$ & n.d. & $0.820 \pm 0.924$ & n.d. \\
\hline Angiotensin II, pg/mL & $42.79 \pm 11.690$ & $41.50 \pm 16.300$ & n.d & n.d. \\
\hline
\end{tabular}




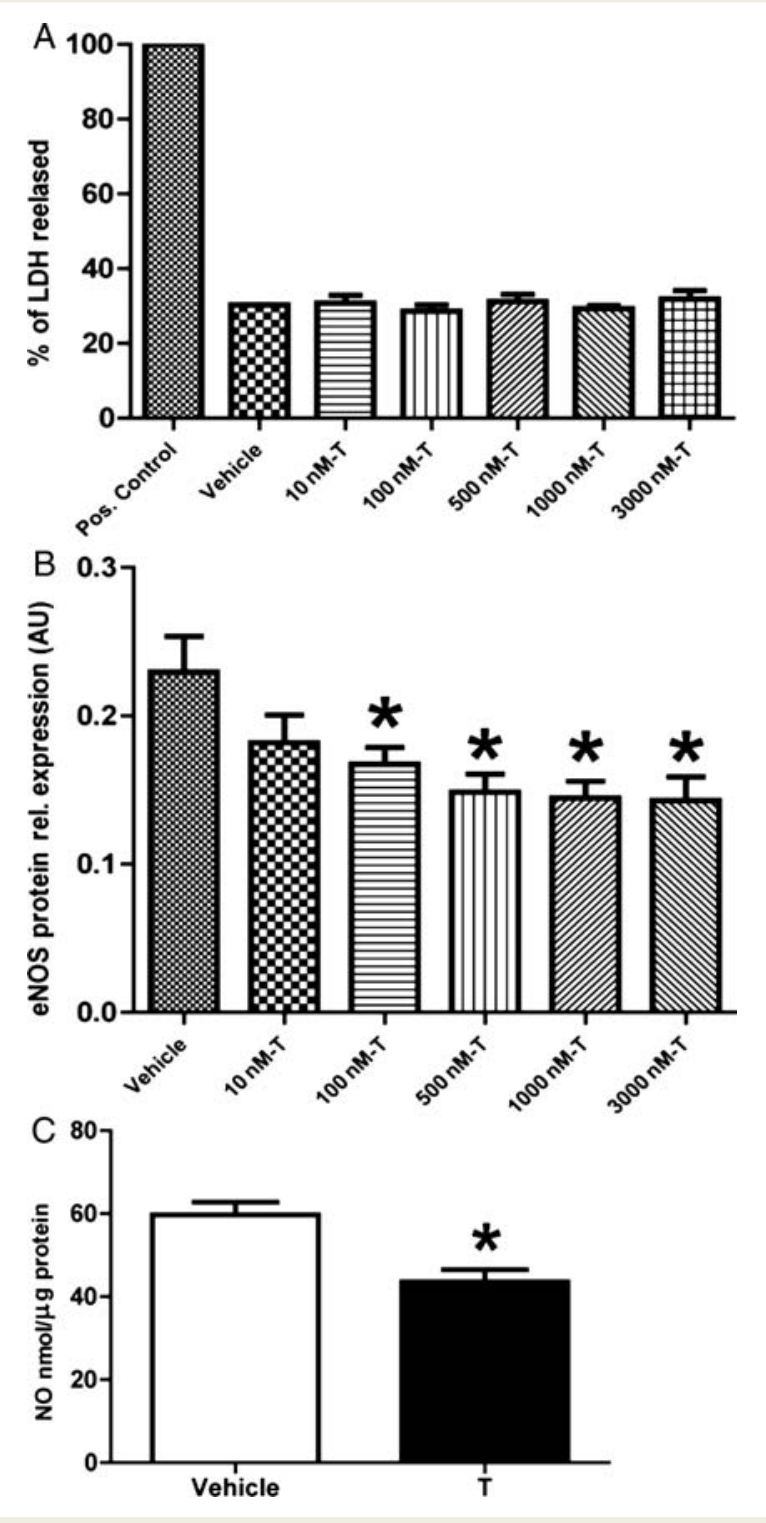

Figure 2 (A) Cell viability assay. Cell culture medium from cells incubated with different torcetrapib concentrations $(10-3000 \mathrm{nM})$ for $24 \mathrm{~h}$ was tested for the presence of lactate dehydrogenase (LDH). There was no difference in cell viability with all tested torcetrapib concentrations. Pos. control, positive control, the cell culture medium with added vehicle and Triton X-100 (2\% in assay medium). (B) Western blot analysis of protein extracts from human aortic endothelial cells treated with torcetrapib for $24 \mathrm{~h}$. Western blot analysis confirmed downregulation of endothelial nitric oxide synthase protein in protein extracts from human aortic endothelial cells treated with torcetrapib in a broad concentration range. Torcetrapib- vs. vehicletreated cells: $* P=0.0467, \quad P=0.0165, \quad P=0.0123$, and $P=0.0165$ for $100,500,1000$, and $3000 \mathrm{nM}$ torcetrapib, respectively. (C) Nitric oxide release from human aortic endothelial cells treated either with $1000 \mathrm{~nm}$ tocetrapib or vehicle for $24 \mathrm{~h}$ measured by electron spin resonance spectroscopy. Human aortic endothelial cells treated with torcetrapib released less nitric oxide when compared with human aortic endothelial cells treated with the vehicle, $* P=0.0050$.
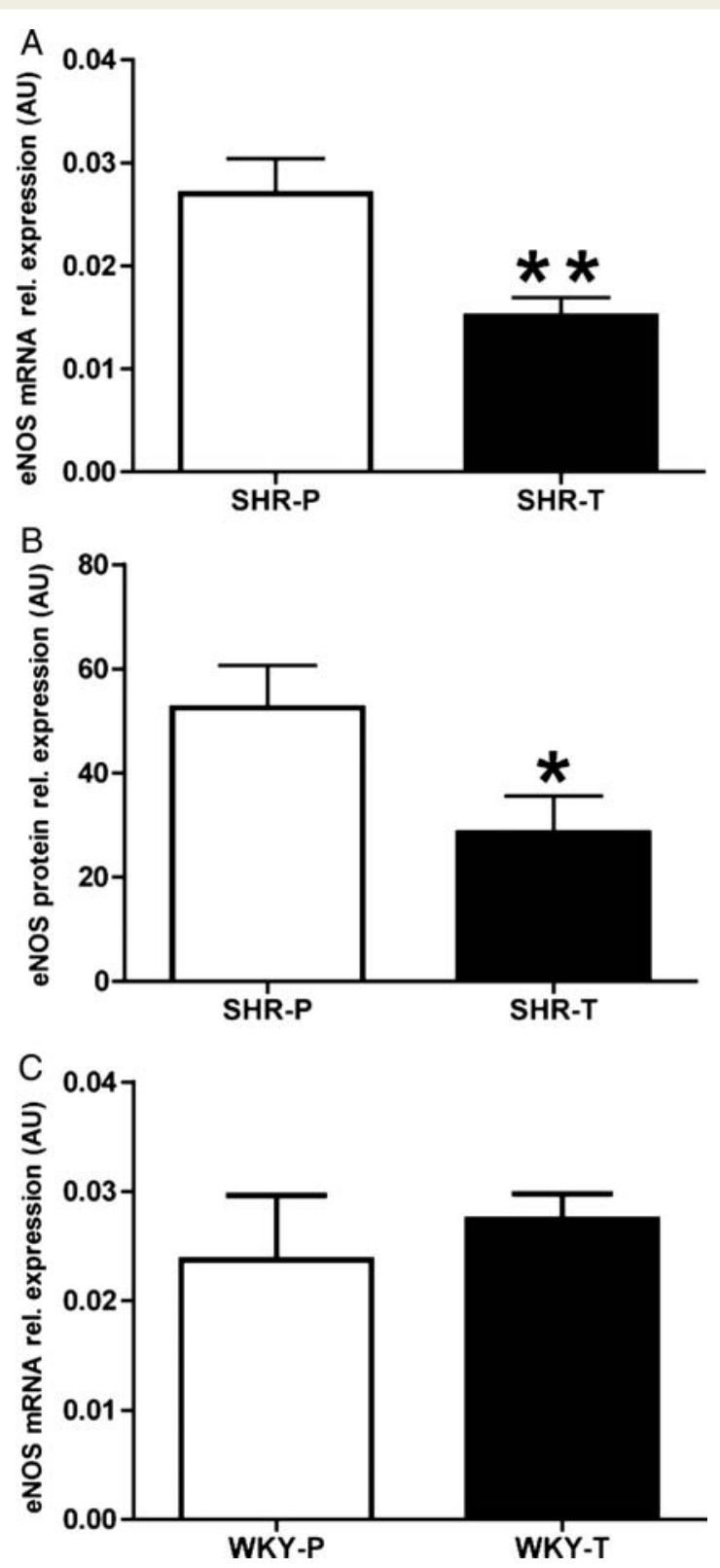

Figure 3 Expression of total endothelial nitric oxide synthase in aortic tissue of spontaneously hypertensive rats. (A) Reverse transcriptase-polymerase chain reaction demonstrated a marked downregulation of endothelial nitric oxide synthase mRNA in the aorta of torcetrapib-treated spontaneously hypertensive rats vs. placebo-treated spontaneously hypertensive rats. ${ }^{*} * P<0.01$. (B) Western blot analysis confirmed tissue down-regulation of endothelial nitric oxide synthase protein in torcetrapib-treated spontaneously hypertensive rats vs. placebo-treated spontaneously hypertensive rats. $* P<0.05$. (C) Expression level of endothelial nitric oxide synthase in aortic tissue of Wistar-Kyoto rats. Reverse transcriptase-polymerase chain reaction demonstrated no change in the endothelial nitric oxide synthase gene expression profile from the aorta of torcetrapib-treated Wistar-Kyoto rats $(\mathrm{WKY}-\mathrm{T})$ vs. placebo-treated Wistar-Kyoto rats (WKYP) $(P=0.5206)$. 


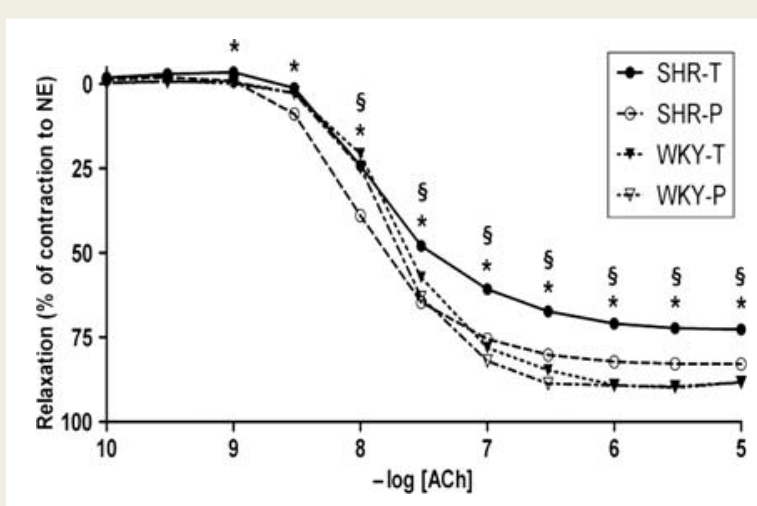

Figure 4 Endothelium-dependent relaxation to acetylcholine in isolated aortic rings pre-contracted with norepinephrine obtained from spontaneously hypertensive rats and WistarKyoto rats. Acetylcholine-induced vasorelaxation was impaired in aortas of torcetrapib-treated spontaneously hypertensive rats (SHR-T) in comparison with placebo-treated spontaneously hypertensive rats (SHR-P), ( $* P<0.0001$ for SHR-T vs. SHR-P) and in SHR-P vs. WKY-P $\left({ }^{\S} P=0.01\right)$.

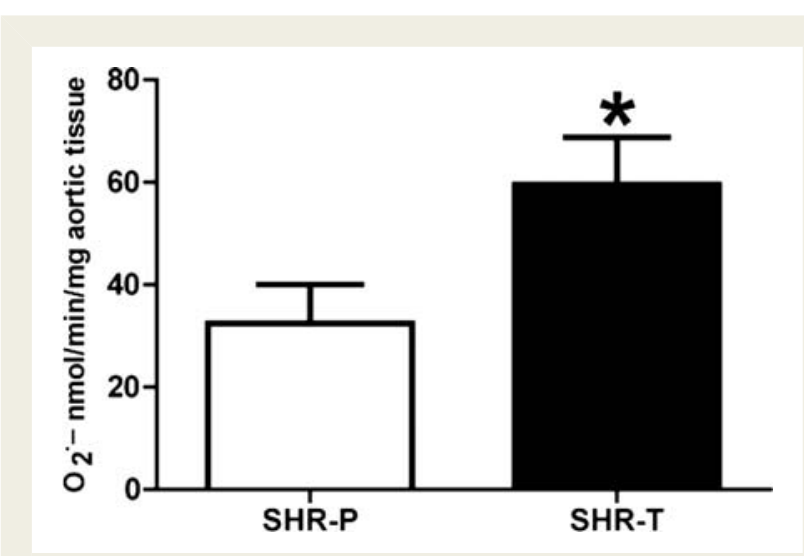

Figure 5 Effect of torcetrapib on the generation of reactive oxygen species in aortas of spontaneously hypertensive rats treated with torcetrapib (SHR-T) when compared with placebo spontaneously hypertensive rats (SHR-P). Reactive oxygen species formation was increased in SHR-T $(P=0.0411$ vs. SHR-P).

\section{Activity of the vascular endothelin system} Vascular reactivity to endothelin-1

Endothelin-1-induced contractions $\left(10^{-8}\right.$ and $\left.10^{-7} \mathrm{M}\right)$ of isolated aortic rings obtained from SHR-T were increased when compared with those obtained from SHR-P $(P=0.0279$ and 0.0243, respectively) (Figure 6). The AUC was increased in SHR-T (+33\%, $P<0.05$ vs. SHR-P, Table 1$)$. The $\mathrm{EC}_{50}$ value $(-\log [M])$ of aortic rings from SHR-T and $\mathrm{EC}_{50}$ value of SHR-P were calculated and averaged 7.998 and 7.965 , respectively (Table 1). Vascular reactivity to ET-1 in WKY rats remained unchanged after torcetrapib treatment (Figure 6).

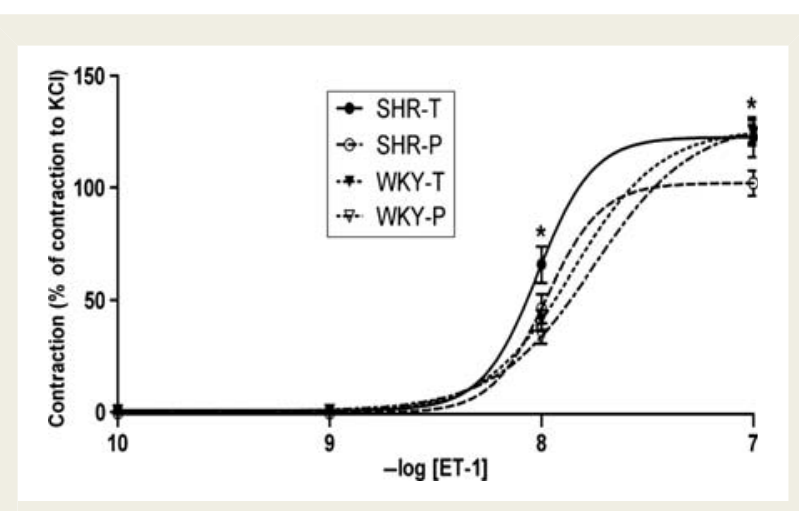

Figure 6 Dose-response curve to endothelin-1 in quiescent isolated aortic rings obtained from spontaneously hypertensive rats and Wistar-Kyoto rats. Endothelin-1-induced vasoconstriction of isolated aortic rings obtained from torcetrapib-treated spontaneously hypertensive rats (SHR-T) was increased compared with those obtained from placebo-treated spontaneously hypertensive rats (SHR-P), $P<0.05$. No change was observed between torcetrapib-treated Wistar-Kyoto rats and placebotreated Wistar-Kyoto rats.

\section{Aortic endothelin tissue levels during torcetrapib treatment}

Tissue content of ET-1 in the aortas of SHR-T was increased $(+49.56 \%, P=0.0154$ vs. SHR-P) (Figure 7). Endothelin-1 tissue levels in WKY-T did not significantly differ from those obtained in WKY-P $(P=0.2764)$.

\section{Aortic endothelin receptor expression during torcetrapib treatment}

The $\mathrm{ET}_{\mathrm{A}}$ gene expression level showed only a tendency for a higher expression, whereas $\mathrm{ET}_{\mathrm{B}}$ gene expression tended to be decreased in SHR-T when compared with SHR-P, as measured by RT-PCR, but this difference was not statistically significant (data not shown).

\section{Immunohistochemistry of endothelin receptors}

Staining intensity of all samples was evaluated based on two independent sections. Endothelin receptor A staining was more pronounced in the endothelium, neo-intima and tunica media of SHR-T when compared with SHR-P (see Supplementary material online, Figure $S 1 A$ and $B$ ). Endothelin receptor $B$ exhibited equally pronounced staining in both the endothelium and neointima layers of SHR-T when compared with SHR-P (see Supplementary material online, Figure S2A and B). All controls, either achieved by incubation with the specific control peptide, or using normal controls analysed without primary antibodies, were negative (see Supplementary material online, Figures S1C and S2C). von Willebrand factor-staining and smooth muscle $\alpha$-actin-staining did not differ between SHR-T and SHR-P (data not shown). In some sections, we observed background at the edge of disrupted adventia which we considered insignificant taking into consideration the small size of these samples.

The analysis of the staining intensities in endothelium cells and vascular smooth muscle cells (VSMCs) for $\mathrm{ET}_{\mathrm{A}}$ and $\mathrm{ET}_{\mathrm{B}}$ receptors 


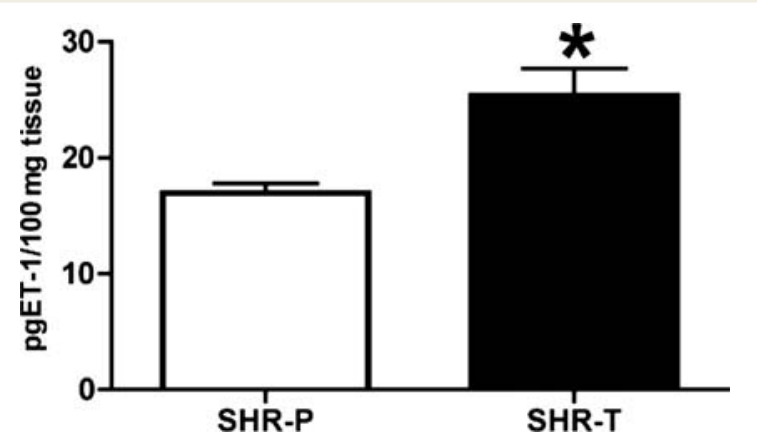

Figure 7 Aortic endothelin-1 tissue content as determined by radioimmunoassay. Torcetrapib-treated spontaneously hypertensive rats showed higher aortic tissue levels of endothelin-1 when compared with placebo-treated spontaneously hypertensive rats. $P<0.05$.

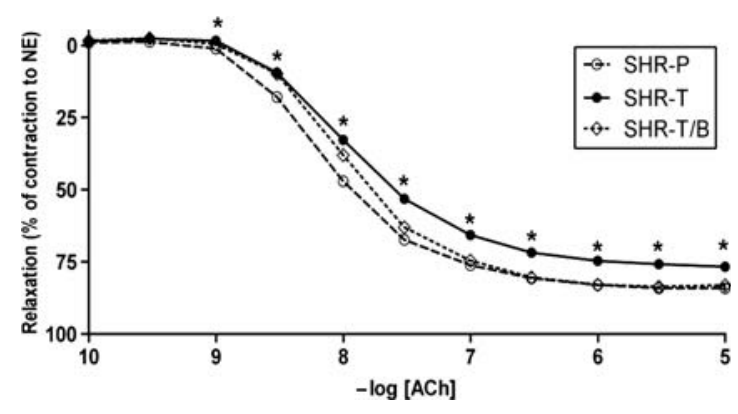

Figure 8 Endothelium-dependent relaxation to acetylcholine in isolated aortic rings pre-contracted with norepinephrine obtained from spontaneously hypertensive rats treated with torcetrapib (SHR-T), placebo spontaneously hypertensive rats (SHR-P), and spontaneously hypertensive rats co-administered with torcetrapib plus the endothelin A/B-receptor antagonist bosentan (SHR-T/B). Acetylcholine-induced vasorelaxation was impaired in aortas of SHR-T in comparison to placebo-treated spontaneously hypertensive rats (SHR-P) while co-administration of endothelin receptor antagonist bosentan normalized endothelial function. SHR-T vs. SHR-P: $* P<0.05$ for $10^{-9}$ and $10^{-5}$ and $P<0.005$ for $10^{-8}$ to $10^{-6} \mathrm{M}$ acetylcholine; SHR-T vs. SHR-T/B: $* P<0.01$ for $10^{-7}-10^{-5} M$ acetylcholine.

was performed using analySIS ${ }^{\circledR}$ software (Soft Imaging System, $\mathrm{GmbH}$, Münich, Germany). No difference in the receptors' density in either endothelium or VSMCs was found for $E_{A}$ or $E T_{B}$ receptors (see Supplementary material online, Figure S3A, B, and $C$ ).

\section{Effects of endothelin receptor blockade Chronic endothelin A/B-blockade and endothelium-dependent relaxation}

Co-administration of bosentan on top of torcetrapib (SHR-T/B) for 3 weeks restored endothelium-dependent relaxations in
SHR-T $\left(P<0.01\right.$ vs. SHR-T/B) (Figure 8). The $\mathrm{EC}_{50}$ values $(-\log [\mathrm{M}])$ of SHR-T, SHR-P, and SHR-T/B were: 7.903, 8.126, and 7.949, respectively $(P<0.001$ SHR-T vs. SHR-P). With bosentan, the area under the curve was increased $(+11.63 \%, P<0.05$ vs. SHR-T, Table 3). Furthermore, maximal relaxation to $\mathrm{ACh}$ increased as well with bosentan (Table 3).

\section{Endothelin A and B receptors' antagonism and endothelin-1-induced contraction}

Pre-treatment with the selective $\mathrm{ET}_{\mathrm{A}}$ receptor antagonist, $\mathrm{BQ}-123$, did not change ET-1-induced contractions of aortic rings. In particular, no difference between SHR-T and SHR-P was observed. After pre-incubation with the selective $\mathrm{ET}_{\mathrm{B}}$ receptor antagonist, BQ-788, ET-1 induced contraction in SHR-T rings remained unchanged, while rings from SHR-P showed a trend in diminished responses to ET-1 at $10^{-8} \mathrm{M}$ (see Supplementary material online, Figure $\mathrm{S} 4 \mathrm{~A}$ and $\mathrm{B}$ ).

\section{Activity of the renin-angiotensin-aldosterone system}

Plasma aldosterone was increased in SHR-T $(+33.72 \%, P=0.0172$ vs. SHR-P, see Supplementary material online, Figure S5C), but remained unchanged within the WKY groups (data not shown). A higher trend in plasma renin activity was found in SHR-T when compared with SHR-P, but not statistically significant. No difference in angiotensin II was found between SHR-T and SHR-P (see Supplementary material online, Figure S5A and B).

\section{Discussion}

This study demonstrates that the CETP inhibitor torcetrapib induces a sustained and marked impairment of endothelial function, decreases eNOS mRNA and protein as well as NO release, stimulates aldosterone secretion as well as vascular ROS and ET production.

The increased cardiovascular events in the ILLUMINATE trial suggested potential off-target effects of torcetrapib. ${ }^{8}$ Indeed, BP elevation was paralleled by an increase in plasma aldosterone, bicarbonate and sodium as well as a reduction in plasma potassium were observed in ILLUMINATE trial. ${ }^{8}$ Since endothelium-derived NO plays a crucial role in the maintenance of endothelial and vascular function $^{23}$ and decreased $\mathrm{NO}$ production has been implicated in the pathogenesis and clinical course of all known cardiovascular diseases and is associated with future risk of adverse cardiovascular events, ${ }^{24-26}$ the effects of torcetrapib on endothelial function in the aorta of SHRs and WKY rats were investigated. SHR treated with torcetrapib showed a marked impairment in ACh-induced endothelial-dependent relaxations, which may represent a clinically relevant mechanism. Interestingly, torcetrapib also down-regulated eNOS mRNA and protein expression in SHR aortas in vivo and decreased direct $\mathrm{NO}$ release in HAECs in vitro, indicating an inhibition of eNOS expression as well as inactivation of $\mathrm{NO}$ by torcetrapib. Intriguingly, torcetrapib stimulated the vascular production of reactive oxygen species in SHR-T. Since the link between increased oxidative stress and reduced bioavailability of $\mathrm{NO}$ has been well established, ${ }^{27,28}$ the present results indicate that oxidative stress 
Table 3 The endothelial parameters analysed in torcetrapib-treated spontaneously hypertensive rats (SHR-T), placebo spontaneously hypertensive rats (SHR-P), and torcetrapib plus bosentan-treated spontaneously hypertensive rats (SHR-T/B).

\begin{tabular}{|c|c|c|c|}
\hline Parameter & SHR-T & SHR-P & SHR-T/B \\
\hline \multicolumn{4}{|l|}{ Acetylcholine } \\
\hline Area under the curve & $214.9 \pm 5.315^{*}$ & $258.1 \pm 7.467$ & $239.9 \pm 6.505^{* *}$ \\
\hline$E C_{50}(M),-\log$ & $7.903 \pm 0.006^{\dagger}$ & $8.126 \pm 0.054$ & $7.949 \pm 0.046$ \\
\hline Maximum (\%) & $76.62 \pm 2.025^{\ddagger}$ & $84.11 \pm 1.481$ & $83.10 \pm 1.312^{\bullet}$ \\
\hline
\end{tabular}

$* P<0.01$ SHR-T vs. SHR-P;

$* * P<0.05$ SHR-T vs. SHR-T/B;

${ }^{\dagger} P<0.01$ SHR-T vs. SHR-P;

${ }^{\ddagger} P<0.01$ SHR-T vs. SHR-P;

" $P<0.05$ SHR-T vs. SHR-T/B.

accounts in parts for the impairment of endothelial function induced by torcetrapib.

Interestingly, torcetrapib increased both vascular reactivity to ET-1 and aortic ET-1 tissue, indicating an activation of the vascular ET system by torcetrapib in SHR. Endothelin-1, a potent endothelial vasoconstrictor peptide formed by endothelial cells, ${ }^{29}$ impacts on salt and water homeostasis and stimulates the reninangiotensin-aldosterone system and plays a pivotal role in vascular remodelling in experimental and human hypertension. ${ }^{30,31}$ To further delineate the mechanisms of ET-1-induced changes on endothelium-dependent vasorelaxation in SHR-T, torcetrapib was administered to SHR and, in parallel, co-administered the $E T_{A / B}$-receptor antagonist bosentan. Of note, chronic $\mathrm{ET}_{\mathrm{A} / \mathrm{B}}$-receptor blockade normalized endothelium-dependent relaxations, indicating that the stimulation of ET-1 is crucially involved in endothelial dysfunction induced by torcetrapib. ${ }^{32}$ Indeed, NO and ET-1 interact with each other both at their site of production in endothelial cells ${ }^{29}$ as well as at their site of action, i.e. in smooth muscle cells. ${ }^{33}$ Hence it is likely that ET-1 down-regulates eNOS expression and stimulates ROS and in turn reduces $\mathrm{NO}$ bioavailability and endothelium-dependent relaxations.

Endothelin-1 modulates biological responses through at least two distinct types of receptors, i.e. $E T_{A}$ and $E T_{B}$ receptors. Endothelin $A$ receptors are predominantly located on VSMCs, ${ }^{34,35}$ whereas $\mathrm{ET}_{\mathrm{B}}$ receptors are expressed both on VSMCs and on endothelial cells. ${ }^{36-38}$ To delineate a possible role of an up-regulation of ET-1 receptors in the observed increased contractile response to ET-1 in SHR-T, aortas obtained from SHR-T and SHR-P were pre-treated with the selective antagonists $\mathrm{ET}_{\mathrm{A}}$ and $\mathrm{ET}_{\mathrm{B}}$ receptors $\mathrm{BQ}-123$ and $\mathrm{BQ}-788$, respectively. However, these experiments revealed no difference of ET-1-induced contraction between SHR-T and SHR-P, suggesting a similar contribution of both receptors to ET-1-induced contraction both in the presence and in the absence of torcetrapib. Similarly, aortic mRNA expression of $\mathrm{ET}_{\mathrm{A}}$ and $\mathrm{ET}_{\mathrm{B}}$ receptors as assessed by RT-PCR did not reveal differences between SHR-T and SHR-P. Likewise, in aortic tissue obtained from all groups of animals, no significant change in receptor distribution between either VSMCs or endothelial cells could be demonstrated by immunohistochemistry. This indicates that torcetrapib-induced changes in the response to ET-1 are not related to different expression levels of $\mathrm{ET}_{\mathrm{A}}$ and $\mathrm{ET}_{\mathrm{B}}$ receptors and/or their distribution in VSCMs or endothelial cells, but may involve different calcium handling in VSMCs. Indeed, torcetrapib appears to activate L-type calcium channels in VSMCs ${ }^{39}$ and inhibition of these channels blunts the response to the peptide in rodents ${ }^{40}$ and in humans. ${ }^{41}$

The increase in ET-1 tissue levels in SHR-T was paralleled by an increase in plasma aldosterone, but not renin or angiotension II levels pointing towards a direct and specific activation of the mineralcorticoid axis by ET-1. Indeed, ET-1 is a potent secretagogue of aldosterone within adrenal glands. ${ }^{42-44}$ The present study supports and extends recent findings by Forrest et al., ${ }^{45}$ as we here demonstrate a transient BP and concomitant and sustained increase in plasma aldosterone after torcetrapib treatment. As BP returned to baseline, the latter phenomenon suggests an aldosterone escape at the level of the kidney and/or resistance vessels.

The impairment of endothelial function is likely to represent an off-target effect of torcetrapib and unrelated to CETP inhibition, as rodents such as the rat are lacking CETP ${ }^{46}$ and lipids remained unchanged under the conditions of the present study. Conversely, in humans, HDL increases the eNOS protein expression thereby off-setting LDL-induced inhibition of eNOS expression in dyslipidaemia and intravenous administration of reconstituted HDL into the human forearm circulation restored $\mathrm{ACh}$-induced endothelial function and flow-mediated vasodilation in hypercholesterolemic patients. ${ }^{47}$ Importantly, we just recently demonstrated that CETP inhibition with dalcetrapib (formerly JTT-705) increased HDL-C and lowered triglycerides but similarly failed to improve endothelial function. ${ }^{17}$ A modest improvement of endothelium-dependent vasodilatation, howewever, was found in the subgroup of patients with low baseline HDL only.

Interestingly, all off-target effects of torcetrapib effects became apparent in SHR only, but not in normotensive WKY rats. This suggests that potential deleterious effects of torcetrapib in the vasculature come into play only with a genetic disposition or presence of arterial hypertension. This is in line with early data on the BP 
effects of torcetrapib in 162 patients with low HDL levels ${ }^{12}$ in which torcetrapib at doses up to $90 \mathrm{mg} /$ day did not increase BP compared with placebo during a treatment period of up to 8 weeks. Interestingly and in line with the former interpretation of our data, all patients of this study were normotensive at baseline with average office $\mathrm{BP}$ values of $123 / 78 \mathrm{mmHg}{ }^{12}$

The BP effects alone, however, do not explain the excess of cardiovascular risk associated with long-term treatment with torcetrapib. However, more than $70 \%$ of all patients included in the ILLUMINATE trial had a history of hypertension, while patients with uncontrolled hypertension were excluded from the trial. Nevertheless, hypertension was still the most frequently observed adverse event $(18.7 \%$ in the torcetrapib vs. $7.5 \%$ in the placebo group). ${ }^{8}$

The specific off-target effects of torcetrapib described in this study, in particular the sustained and marked impairment of endothelial function, decreased NO-bioavailability and increased ROS production as well as activation of the ET, aldosterone, may at least in part explain the increased mortality associated with torcetrapib treatment in the ILLUMINATE trial. Thus, careful assessment of vascular toxicity is mandatory for the development of other CETP inhibitors. Indeed, as outlined by Pfeffer and Sacks, ${ }^{48}$ studies with surrogate endpoints, such as lipids or vascular imaging studies, remain hypothesis generating at best and cannot provide sufficient safety information. Therefore, the question whether CETP inhibition has atheroprotective or proatherogenic role in humans may be answered only when ongoing adequately powered randomized morbidity and mortality trials are completed. Although novel CETP inhibitors such as dalcetrapib and anacetrapib up to now did not appear to have off-target adverse effects on BP and adrenal function, their vascular protective effects are far from established. ${ }^{49}$ Since the results of the present study unequivocally demonstrate substantial off-target effects of one of the members of the class of CETP inhibitors unrelated to CETP inhibition, the absence of evidence does not provide evidence of the absence of such off-target effects with the other members of the class. Importantly, BP is unlikely to explain all of the excess morbidity and mortality associated with the use of torcetrapib. Indeed, in the present study, substantial impairment of endothelial function was still present after 3 weeks, a long time after BP already had returned to baseline. As such, the results of the just recently presented DEFINE trial $^{50}$ need to be put in perspective, as the absence of a BP increase associated with the use of anacetrapib does not allow to exclude BP independent offtarget effects, endothelial impairment in particular.

Whether and to what degree these unpredicted and potentially deleterious off-target effects are molecule-specific or represent a class effect of CETP inhibitors needs to be ruled out in the clinical development of other CETP inhibitors, such as anacetrapib and dalcetrapib before a large patient population, particularly when at increased cardiovascular risk, is exposed to these compounds.

\section{Supplementary material}

Supplementary material is available at European Heart Journal online.

\section{Acknowledgements}

We would like to thank to Jane Boden Shaw for her excellent work on quantification of ET-1, renin, and angiotensin II. Additionally, we would like to express our gratitude towards Prof. Dr Anne-Catherine Andres and Carlos Wotzkow from the Department of Clinical Research, Medical Faculty of the University of Bern, Switzerland, for their invaluable help in immunohistochemical analysis. We highly appreciate help from Dr Marc Iglarc, Actelion Pharmaceuticals Ltd, Switzerland, for his kindness to provide us with bosentan used in our study. We are grateful to Prof. Theo Gasser for his support in statistical interpretation of the data.

\section{Funding}

B.S. was supported for his work by an Educational Grant through the Strategic Alliance of the Foundation of Cardiovascular Research and the University of Zurich, Switzerland with Pfizer Inc., New York, USA. Furthermore, this work was supported by the Swiss National Research Foundation (Nr. 310030-118353 to T.F.L.).

Conflict of interest: The authors declared no conflict of interest in connection to this paper except funding provided via the Strategic Alliance with Pfizer Inc., New York, USA.

\section{References}

1. Assmann G, Schulte H, von Eckardstein A, Huang Y. High-density lipoprotein cholesterol as a predictor of coronary heart disease risk. The PROCAM experience and pathophysiological implications for reverse cholesterol transport. Atherosclerosis 1996;124(Suppl):S11-20.

2. Curb JD, Abbott RD, Rodriguez BL, Masaki K, Chen R, Sharp DS, Tall AR. A prospective study of HDL-C and cholesteryl ester transfer protein gene mutations and the risk of coronary heart disease in the elderly. J Lipid Res 2004;45:948-953.

3. Sharrett AR, Ballantyne CM, Coady SA, Heiss G, Sorlie PD, Catellier D, Patsch W. Coronary heart disease prediction from lipoprotein cholesterol levels, triglycerides, lipoprotein(a), apolipoproteins $\mathrm{A}-\mathrm{I}$ and $\mathrm{B}$, and $\mathrm{HDL}$ density subfractions: The Atherosclerosis Risk in Communities (ARIC) Study. Circulation 2001;104 $1108-1113$.

4. Rubins HB, Robins SJ, Collins D, Fye CL, Anderson JW, Elam MB, Faas FH, Linares E, Schaefer EJ, Schectman G, Wilt TJ, Wittes J. Gemfibrozil for the secondary prevention of coronary heart disease in men with low levels of highdensity lipoprotein cholesterol. Veterans Affairs High-Density Lipoprotein Cholesterol Intervention Trial Study Group. N Engl J Med 1999;341:410-418.

5. Shepherd J, Betteridge J, Van Gaal L. Nicotinic acid in the management of dyslipidaemia associated with diabetes and metabolic syndrome: a position paper developed by a European Consensus Panel. Curr Med Res Opin 2005;21:665-682.

6. Cushman WC, Evans GW, Byington RP, Goff DC Jr, Grimm RH Jr, Cutler JA, Simons-Morton DG, Basile JN, Corson MA, Probstfield JL, Katz L, Peterson KA, Friedewald WT, Buse JB, Bigger JT, Gerstein HC, Ismail-Beigi F. Effects of intensive blood-pressure control in type 2 diabetes mellitus. N Engl J Med 2010;362: 1575-1585.

7. Barter PJ, Brewer HB Jr, Chapman MJ, Hennekens CH, Rader DJ, Tall AR. Cholesteryl ester transfer protein: a novel target for raising HDL and inhibiting atherosclerosis. Arterioscler Thromb Vasc Biol 2003;23:160-167.

8. Barter PJ, Caulfield M, Eriksson M, Grundy SM, Kastelein JJ, Komajda M, Lopez-Sendon J, Mosca L, Tardif JC, Waters DD, Shear CL, Revkin JH, Buhr KA, Fisher MR, Tall AR, Brewer B. Effects of torcetrapib in patients at high risk for coronary events. N Engl J Med 2007;357:2109-2122.

9. Kastelein JJ, van Leuven SI, Burgess L, Evans GW, Kuivenhoven JA, Barter PJ, Revkin JH, Grobbee DE, Riley WA, Shear CL, Duggan WT, Bots ML. Effect of torcetrapib on carotid atherosclerosis in familial hypercholesterolemia. N Engl J Med 2007;356:1620-1630.

10. Bots ML, Visseren FL, Evans GW, Riley WA, Revkin JH, Tegeler CH, Shear CL, Duggan WT, Vicari RM, Grobbee DE, Kastelein J]. Torcetrapib and carotid intima-media thickness in mixed dyslipidaemia (RADIANCE 2 study): a randomised, double-blind trial. Lancet 2007;370:153-160.

11. Nissen SE, Tardif JC, Nicholls SJ, Revkin JH, Shear CL, Duggan WT, Ruzyllo W, Bachinsky WB, Lasala GP, Tuzcu EM. Effect of torcetrapib on the progression of coronary atherosclerosis. N Engl J Med 2007;356:1304-1316. 
12. Davidson MH, McKenney JM, Shear CL, Revkin JH. Efficacy and safety of torcetrapib, a novel cholesteryl ester transfer protein inhibitor, in individuals with below-average high-density lipoprotein cholesterol levels. I Am Coll Cardiol 2006;48:1774-1781

13. McKenney JM, Davidson MH, Shear CL, Revkin JH. Efficacy and safety of torcetrapib, a novel cholesteryl ester transfer protein inhibitor, in individuals with below-average high-density lipoprotein cholesterol levels on a background of atorvastatin. J Am Coll Cardiol 2006;48:1782-1790.

14. Krishna R, Bergman AJ, Jin B, Fallon M, Cote J, Van Hoydonck P, Laethem T, Gendrano IN III, Van Dyck K, Hilliard D, Laterza O, Snyder K, Chavez-Eng C, Lutz R, Chen J, Bloomfield DM, De Smet M, Van Bortel LM, Gutierrez M, Al-Huniti N, Dykstra K, Gottesdiener KM, Wagner JA. Multiple-dose pharmacodynamics and pharmacokinetics of anacetrapib, a potent cholesteryl ester transfer protein (CETP) inhibitor, in healthy subjects. Clin Pharmacol Ther 2008;84: $679-683$.

15. de Grooth GJ, Kuivenhoven JA, Stalenhoef AF, de Graaf J, Zwinderman AH, Posma JL, van Tol A, Kastelein JJ. Efficacy and safety of a novel cholesteryl ester transfer protein inhibitor, JTT-705, in humans: a randomized phase II doseresponse study. Circulation 2002;105:2159-2165.

16. Kuivenhoven JA, de Grooth G], Kawamura H, Klerkx AH, Wilhelm F, Trip MD, Kastelein J. Effectiveness of inhibition of cholesteryl ester transfer protein by JTT-705 in combination with pravastatin in type II dyslipidemia. Am J Cardiol 2005;95:1085-1088

17. Hermann F, Enseleit F, Spieker LE, Periat D, Sudano I, Hermann M, Corti R, Noll G, Ruschitzka F, Luscher TF. Cholesterylestertransfer protein inhibition and endothelial function in type II hyperlipidemia. Thromb Res 2009;123:460-465.

18. Hermann M, Camici G, Fratton A, Hurlimann D, Tanner FC, Hellermann JP, Fiedler M, Thiery J, Neidhart M, Gay RE, Gay S, Luscher TF, Ruschitzka F. Differential effects of selective cyclooxygenase-2 inhibitors on endothelial function in salt-induced hypertension. Circulation 2003;108:2308-2311.

19. Bradford MM. A rapid and sensitive method for the quantitation of microgram quantities of protein utilizing the principle of protein-dye binding. Anal Biochem 1976;72:248-254

20. Laemmli UK. Cleavage of structural proteins during the assembly of the head of bacteriophage T4. Nature 1970;227:680-685.

21. Shaw SG, Schmid M, Casty A. Critical factors in the radioimmunoassay of endothelin-1, endothelin-3, and big endothelin-1 in human plasma. Anal Biochem 2000;278:143-149.

22. Sorrentino SA, Besler C, Rohrer L, Meyer M, Heinrich K, Bahlmann FH, Mueller M, Horvath T, Doerries C, Heinemann M, Flemmer S, Markowski A, Manes C, Bahr MJ, Haller H, von Eckardstein A, Drexler H, Landmesser U. Endothelial-vasoprotective effects of high-density lipoprotein are impaired in patients with type 2 diabetes mellitus but are improved after extended-release niacin therapy. Circulation 2010;121:110-122.

23. Loscalzo J. Nitric oxide and vascular disease. N Engl J Med 1995;333:251-253.

24. Fichtlscherer S, Breuer S, Zeiher AM. Prognostic value of systemic endothelial dysfunction in patients with acute coronary syndromes: further evidence for the existence of the 'vulnerable' patient. Circulation 2004;110:1926-1932.

25. Bugiardini R, Manfrini O, Pizzi C, Fontana F, Morgagni G. Endothelial function predicts future development of coronary artery disease: a study of women with chest pain and normal coronary angiograms. Circulation 2004;109:2518-2523.

26. Ross R. The pathogenesis of atherosclerosis: a perspective for the 1990s. Nature 1993;362:801-809.

27. Li H, Witte K, August M, Brausch I, Godtel-Armbrust U, Habermeier A, Closs El, Oelze M, Munzel T, Forstermann U. Reversal of endothelial nitric oxide synthase uncoupling and up-regulation of endothelial nitric oxide synthase expression lowers blood pressure in hypertensive rats. J Am Coll Cardiol 2006;47:2536-2544.

28. Keaney JF Jr. Oxidative stress and the vascular wall: NADPH oxidases take center stage. Circulation 2005;112:2585-2588.

29. Boulanger C, Luscher TF. Release of endothelin from the porcine aorta. Inhibition by endothelium-derived nitric oxide. J Clin Invest 1990;85:587-590.

30. Luscher TF, Barton M. Endothelins and endothelin receptor antagonists: therapeutic considerations for a novel class of cardiovascular drugs. Circulation 2000; 102:2434-2440
31. Bouallegue A, Daou GB, Srivastava AK. Endothelin-1-induced signaling pathways in vascular smooth muscle cells. Curr Vasc Pharmacol 2007;5:45-52

32. Vergeer M, Stroes ES. The pharmacology and off-target effects of some cholesterol ester transfer protein inhibitors. Am / Cardiol 2009;104(10 Suppl):32E-38E.

33. Luscher TF, Yang Z, Tschudi M, von Segesser L, Stulz P, Boulanger C, Siebenmann R, Turina M, Buhler FR. Interaction between endothelin-1 and endothelium-derived relaxing factor in human arteries and veins. Circ Res 1990; 66:1088-1094.

34. Hosoda K, Nakao K, Hiroshi A, Suga S, Ogawa Y, Mukoyama M, Shirakami G, Saito $Y$, Nakanishi S, Imura H. Cloning and expression of human endothelin-1 receptor cDNA. FEBS Lett 1991;287:23-26.

35. MacLean MR, McCulloch KM, Baird M. Endothelin ETA- and ETB-receptor-mediated vasoconstriction in rat pulmonary arteries and arterioles. J Cardiovasc Pharmacol 1994;23:838-845.

36. Seo B, Oemar BS, Siebenmann R, von Segesser L, Luscher TF. Both ETA and ETB receptors mediate contraction to endothelin- 1 in human blood vessels. Circulation 1994;89:1203-1208.

37. Ogawa Y, Nakao K, Arai H, Nakagawa O, Hosoda K, Suga S, Nakanishi S, Imura H. Molecular cloning of a non-isopeptide-selective human endothelin receptor. Biochem Biophys Res Commun 1991;178:248-255.

38. Davenport AP, O'Reilly G, Molenaar P, Maguire Jj, Kuc RE, Sharkey A, Bacon CR, Ferro A. Human endothelin receptors characterized using reverse transcriptasepolymerase chain reaction, in situ hybridization, and subtype-selective ligands BQ123 and BQ3020: evidence for expression of ETB receptors in human vascular smooth muscle. J Cardiovasc Pharmacol 1993;22(Suppl 8):S22-25.

39. Clerc RG, Stauffer A, Weibel F, Hainaut E, Perez A, Hoflack JC, Benardeau A, Pflieger P, Garriz JM, Funder JW, Capponi AM, Niesor EJ. Mechanisms underlying off-target effects of the cholesteryl ester transfer protein inhibitor torcetrapib involve L-type calcium channels. J Hypertens 2010;28:1676-1686.

40. Nayler WG, Liu JJ, Panagiotopoulos S. Nifedipine and experimental cardioprotection. Cardiovasc Drugs Ther 1990;4(Suppl 5):879-885.

41. Kiowski W, Luscher TF, Linder L, Buhler FR. Endothelin-1-induced vasoconstriction in humans. Reversal by calcium channel blockade but not by nitrovasodilators or endothelium-derived relaxing factor. Circulation 1991;83:469-475.

42. Nussdorfer GG, Rossi GP, Malendowicz LK, Mazzocchi G. Autocrine-paracrine endothelin system in the physiology and pathology of steroid-secreting tissues. Pharmacol Rev 1999;51:403-438.

43. Rossi GP, Andreis PG, Neri G, Tortorella C, Pelizzo MR, Sacchetto A, Nussdorfer GG. Endothelin-1 stimulates aldosterone synthesis in Conn's adenomas via both $A$ and $B$ receptors coupled with the protein kinase $C$ - and cyclooxygenase-dependent signaling pathways. J Investig Med 2000;48:343-350.

44. Delarue C, Conlon JM, Remy-Jouet I, Fournier A, Vaudry H. Endothelins as local activators of adrenocortical cells. J Mol Endocrinol 2004;32:1-7.

45. Forrest MJ, Bloomfield D, Briscoe RJ, Brown PN, Cumiskey AM, Ehrhart J, Hershey JC, Keller WJ, Ma X, McPherson HE, Messina E, Peterson LB, Sharif-Rodriguez W, Siegl PK, Sinclair PJ, Sparrow CP, Stevenson AS, Sun SY, Tsai C, Vargas H, Walker M 3rd, West SH, White V, Woltmann RF. Torcetrapib-induced blood pressure elevation is independent of CETP inhibition and is accompanied by increased circulating levels of aldosterone. Br J Pharmacol 2008;154:1465-1473.

46. Zak Z, Gautier T, Dumont L, Masson D, Deckert V, Duverneuil L, Pais De Barros JP, Le Guern N, Schneider M, Moulin P, Bataillard A, Lagrost L. Effect of cholesteryl ester transfer protein (CETP) expression on diet-induced hyperlipidemias in transgenic rats. Atherosclerosis 2005;178:279-286.

47. Spieker LE, Sudano I, Hurlimann D, Lerch PG, Lang MG, Binggeli C, Corti R, Ruschitzka F, Luscher TF, Noll G. High-density lipoprotein restores endothelial function in hypercholesterolemic men. Circulation 2002;105:1399-1402.

48. Pfeffer MA, Sacks FM. Leapfrogging data: no shortcuts for safety or efficacy information. Circulation 2008;118:2491-2494.

49. Shah PK. The yin and yang of cholesteryl ester transfer protein in cardiovascular disease. Circulation 2009;120:2408-2410.

50. Cannon CP, Shah S, Dansky HM, Davidson M, Brinton EA, Gotto AM, Stepanavage M, Liu SX, Gibbons P, Ashraf TB, Zafarino J, Mitchel Y, Barter P. Safety of anacetrapib in patients with or at high risk for coronary heart disease. N Engl J Med 2010;363:2406-2415. 